\title{
Ebelik Bölümünde Öğrenim Gören Öğrencilerin Üniversite Öğrenimi Sırasında Sağlığı ilgilendiren Riskli Davranışları *
}

\section{Health Related Risky Behaviors of University Students Studying at Midwifery Department}

Şükran Ertekin Pınari

'Doç. Dr., Sivas Cumhuriyet Üniversitesi Sağlık Bilimleri Fakültesi, Ebelik Bölümü https://orcid.org/0000-0002-5431-8159 öz

Amaç: Araştırma ebelik bölümünde öğrenim gören öğrencilerin üniversite öğrenimi sırasında sağlığı ilgilendiren riskli davranışlarının belirlenmesi amacı ile yapıımıştır.

Yöntem: Tanımlayıcı araştırmanın evrenini 310 ebelik öğrencisi, örneklemi ise 11 Şubat 2019-22 Şubat 2019 tarihleri arasında, iç Anadolu Bölgesi'nde yer alan bir üniversitenin Sağlık Bilimleri Fakültesi Ebelik Bölümü’nün 1., 2., 3. ve 4. sınıfında öğrenim gören 265 öğrenci oluşturmuştur. Veriler Öğrenci Bilgi Formu ve Riskli Davranışlar Ölçeği-Üniversite Formu ile toplanmış, t, Anova ve Tukey testi ile analiz edilmiş, $\mathrm{p}<0.05$ anlamlı olarak alınmıştır.

Bulgular: Araştırmaya alınan 265 öğrenci arasında alkol ( $p=0.007)$ ve madde kullanımı ( $p=0.040)$, beslenme alışkanlığı ( $p=0.009)$, okul terki $(p=0.003)$ üçüncü sınıf öğrencilerinde; intihar eğilimi $(p=0.012)$ ise ikinci sınıf öğrencilerinde anlamlı düzeyde yüksektir. Alkol ( $p=0.039)$, madde $(p=0.023)$ ve sigara kullanımı $(p=0.043)$, antisosyal davranış $(p=0.006)$, intihar eğilimi $(p=0.006)$ ve okul terki $(p=0.000)$ akademik başarısını orta düzeyde belirten öğrencilerde anlamlı düzeyde daha yüksek saptanmıştır. Sigara kullanımı evde arkadaşları ile yaşayan öğrencilerde ( $p=0.004)$; alkol kullanımı aylık gelirinin yeterli olduğunu belirtenlerde $(p=0.035)$; intihar eğilimi ( $p=0.008)$ ve okul terki $(p=0.006)$ mesleği kendi isteği dışında seçenlerde; intihar eğilimi $(p=0.003)$ ise mesleği kendine uygun bulmayan öğrencilerde anlamlı düzeyde daha yüksektir.

Sonuç: Alkol-madde kullanımı ve beslenme alışkanlığı üçüncü sınıf, intihar eğilimi ikinci sınıf öğrencilerinde yüksektir. Alkol, madde ve sigara kullanımı, antisosyal davranış, intihar eğilimi ve okul terki akademik başarısını orta düzeyde belirten öğrencilerde yüksektir. Evde arkadaşları ile yaşayan öğrencilerde sigara, aylık geliri yeterli olanlarda alkol kullanımı, mesleği kendi seçmeyenlerde intihar eğilimi ve okul terki, mesleği kendine uygun bulmayanlarda da intihar eğilimi daha yüksektir.

Anahtar Kelimeler: Ebelik, Davranış, Öğrenci, Risk, Üniversite

\section{ABSTRACT}

Objective: This study was carried out to determine the health related risky behaviors of university students studying at midwifery department.

Methods: The population of this descriptive study consisted of 310 and the sample consisted of 2651 st, 2nd, 3rd and 4th grade students studying at Faculty of Health Sciences Midwifery Department of a university located in Central Anatolia region between Februa ry 11 and February 22, 2019. Data were collected using Student Information Form and University Form of Risk Behavaiors Scale, and analyzed by $t$, Anova and Tukey test, $\mathrm{p}<0.05$ was accepted significant.

Results: Among 265 students in the study, alcohol ( $p=0.007)$, substance abuse $(p=0.040)$, nutritional habit $(p=0.009)$, drop-out ( $p=0.003)$ were statistically significantly higher among third-grade students, and suicidality $(p=0.012)$ was statistically significantly higher among second-grade students. Alcohol $(p=0.039)$, substance abuse $(p=0.023)$, smoking habit $(p=0.043)$, anti-social behavior $(p=0.006)$, suicidality $(p=0.006)$ and drop-out $(p=0.000)$ were significantly higher among students who perceived their academic achievement at a moderate level. Smoking habit was statistically significantly higher among students living at home with friends $(p=0.004)$; alcohol use among those who expressed their monthly income sufficient $(p=0.035)$; suicidality $(p=0.008)$ and drop-out $(p=0.006)$ among those who stated that they did not choose the profession voluntarily and suicidality $(p=0.003)$ among those who did not find the profession suitable for themselves $(p<0.05)$.

Conclusion: Alcohol, substance abuse and nutritional habits were higher among third-grade, suicidality among second-grade students. Alcohol, substance abuse, smoking habit, anti-social behavior, suicidality and drop-out were higher among students who perceived their academic achievement at a moderate level. Smoking habit was higher among students living at home with friends; alcohol use among those expressing their monthly income sufficient; suicidality and drop-out among those not choosing the profession voluntarily and suicidality among those not finding the profession suitable for themselves.

Key words: Midwifery, Behavior, Student, Risky, University

*Lokman Hekim Dergisi, 2020; 10 (3): 458-467

DOI: $10.31020 /$ mutftd. 723914

e-ISSN: 1309-8004, ISSN 1309-761X

Geliş Tarihi - Received: 22 Nisan 2020; Kabul Tarihi - Accepted: 21 Ağustos 2020

iletişim - Correspondence Author: Şükran Ertekin Pınar <sepinar09@gmail.com>

Etik Onay: Cumhuriyet Üniversitesi Girişimsel Olmayan Klinik Araştırmalar Etik Kurulu (karar no: 2019-01/33) 


\section{Giriş}

Üniversite dönemi, 18-25 yaşları arasına denk gelen ve yetişkinliğe geçişin yaşandığı genç erişkinlik dönemini oluşturmaktadır. ${ }^{1}$ Gençler için üniversiteye girmek, yaşamlarındaki değişimin en önemli aşamalarından birini oluşturmakta, çoğunluğu evlerinden uzakta yaşamaktadır. ${ }^{2}$ Bu dönemde öğrencilerin mesleki, sosyal ve kimlik gelişimleri önem kazanmakta, kendini tanıma, problem çözme, karar verme ve sosyal etkileşim için gerekli becerileri kazanması beklenmektedir. Ayrıca öğrencilerin yaşam tarzındaki değişiklikler bireylere yeni deneyimler sunmakta ve sağlıklı bir yaşam biçimi seçmelerine engel olabilmektedir. Yaşam tarzındaki değişimler, yaşanan gerilim ve stresörlerle başa çıkabilmek için öğrenciler riskli davranışlara yönelebilmektedir. ${ }^{2,3}$ Üniversite yaşamı sırasında edinilen bu riskli davranışlar gelecekte de devam ederek birey, yaşamını bu riskli davranışlarla sürdürebilmektedir. ${ }^{4}$

Riskli Sağlık Davranışları, istemli ve istemsiz yaralanmalara neden olan davranışları ve cinsel davranışları oluşturmakla beraber, bireyin alkol ve madde kullanım durumunu, beslenme alışkanlıklarını ve fiziksel aktivitesini de kapsamaktadır. ${ }^{5}$ Riskli davranışlar bireyin sağlığını doğrudan ya da dolaylı olarak etkileyerek, kişilik yapısından, geçmiş gelişim dönemlerinden ve sosyal çevresindeki bireylerin davranışlarından

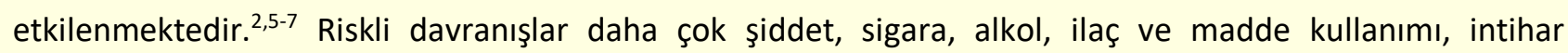
davranışı, okul terki, riskli cinsel yaşam, kötü beslenme, yetersiz fiziksel aktivite, dikkatsiz araba kullanımı şeklinde ortaya çıkmakta ve gençlerde ölüme götüren sonuçlara neden olabilmektedir. ${ }^{1,5,7,8}$ Ergenler ve gençler tarafından tütün ve tütün ürünleri, alkol ve yasadışı uyuşturucu tüketimi tüm dünyada yaygınlaşmakta ve önemli bir halk sağlığı sorununu oluşturmaktadır. ${ }^{9}$

Sağlığı ilgilendiren riskli davranışlar üniversite öğrencileri arasında yüksek oranda görülmektedir. ${ }^{10-14}$ Bununla beraber literatürde doktorluk, hemşirelik, ebelik, diş hekimliği gibi sağlık ile ilgili mesleklerde öğrenim gören öğrencilerde sıklıkla sigara, madde, alkol kullanımı, antisosyal davranış, okul terki, intihar eğilimi, hızlı araba kullanma, şiddet ve saldırganlık, cinsel davranış ve beslenme alışkanlığına yönelik riskli davranışların görüldüğg̈ bildirilmektedir. ${ }^{15-21}$ Riskli davranışlar gençleri fiziksel, psikolojik, sosyal ve mesleki açıdan olumsuz etkileyebilmekte, ölüm, sakatlık ve kronik hastalıkların erken dönemde görülme sıklığını artırmaktadır. ${ }^{19,20}$ Ebe adaylarının henüz öğrencilik yaşantısında riskli davranışlara sahip olmaları gelecekte sağlıklarının erken dönemde bozulmasına, bakım verdikleri gebeler, aileler ve toplum için olumsuz örnek oluşturmalarına neden olabilmektedir. ${ }^{20}$ Ayrıca ebeler sağlığın korunması ve geliştirilmesinde de önemli rol oynamaktadır. ${ }^{21}$ Durumun saptanması ve riskli öğrencilerin belirlenmesi, önlemeye yönelik eğitim ve danışmanlıkların planlanması, geleceğin profesyonelleri olacak ebelik öğrencilerinin fiziksel, ruhsal, sosyal ve mesleki sağııklarının korunması açısından önem taşımaktadır. Yapılan bir araştırmada üniversite öğrencilerine uygulanan eğitim programının riskli davranışları azaltmada etkili olması durumun saptanarak eğitim, danışmanlık gibi uygulamaların önemine vurgu yapmaktadır. ${ }^{14}$ Literatürde özellikle ebelik bölümünde öğrenim gören öğrencilerin yer aldığı ve genel riskli davranışların araştırıldığı çalışmalara rastlanmamıştır. Bu bağlamda ebelik bölümünde öğrenim gören öğrencilerin üniversite öğrenimi sırasında sağlığı ilgilendiren riskli davranışlarının hangi düzeyde olduğu sorusundan yola çıkarak araştırmanın yapılması amaçlanmıştır.

\section{Gereç ve Yöntem}

\section{Evren ve Örneklem}

Tanımlayıcı türdeki araştırmanın evrenini 2018-2019 eğitim öğretim yılının bahar döneminde iç̧ Anadolu Bölgesinde yer alan bir üniversitenin Sağlık Bilimleri Fakültesi Ebelik Bölümü’nde öğrenim gören tüm öğrenciler oluşturmuştur. Ebelik Bölümü'nde toplam 310 kayıtı öğrenci bulunmaktadır. Araştırmada örneklem seçimine gidilmemiş, çalışmamıza katılmaya gönüllü olan, araştırmanın yapıldığı dönemde 
kendisine ulaşılabilen, 1., 2., 3. ve 4. sınıfta öğrenim görmekte olan 265 öğrenci örneklemi oluşturmuştur (katılım oranı: \%85.4). Araştırma verileri 11 Şubat 2019-22 Şubat 2019 tarihleri arasında toplanmıştır.

\section{Veri Toplama Araçları}

Verilerinin toplanmasında, Öğrenci Bilgi Formu ve Riskli Davranışlar Ölçeği-Üniversite Formu kullanılmıştır.

Öğrenci Bilgi Formu, katılımcıların yaş, sınıf, cinsiyet, aile tipi, yaşadığı yer, anne-baba eğitimi, anne-baba çalışma durumu, aylık geliri, mesleği seçme ve kendine uygun bulma durumu, akademik başarısı, sigara ve nargile kullanma durumu gibi özelliklerini belirlemek amacıyla oluşturulmuş, toplam 15 sorudan oluşan formdur.

Riskli Davranışlar Ölçeği-Üniversite Formu (RDÖÜF), Gençtanırım tarafından 2014 yılında geliştirilmiş 60 maddelik bir ölçektir ve beşli likert tipindedir. ${ }^{3}$ Ölçek, antisosyal davranışlar (1-10. maddeler), alkol kullanımı (11-19. maddeler), sigara kullanımı (20-27. maddeler), intihar eğilimi (28-39. maddeler), beslenme alışkanlıkları (40-47. maddeler), okul terki (48-51. maddeler) ve madde kullanımından (52-60. maddeler) oluşan yedi alt boyuta sahiptir. Alt boyutlardan alınan puan arttıkça riskin arttı̆ı̆ını göstermektedir. Gençtanırım tarafından alt boyutların Cronbach Alpha katsayıları 0.64 ile 0.92 arasında saptanmıştır. ${ }^{3}$ Bu araştırmada ise Cronbach Alpha katsayısı antisosyal davranış için 0.70; alkol kullanımı için 0.88; sigara kullanımı için 0.90; intihar eğilimi için 0.89; beslenme alışkanlıkları için 0.83; okul terki için 0.64 ve madde kullanımı için 0.79 olarak bulunmuştur.

\section{Veri Toplama}

Ebelik bölümünde öğrenim gören öğrencilere sınıf ortamlarında araştırma konusu ve amacı açıklanmış, bilgilendirilmiş onamları alınmıştır. Formlar, araştırmaya katılmayı kabul eden öğrencilere araştırmacı tarafından tek oturumda uygulanmıştır. Formların doldurulması yaklaşık olarak 10 dakika sürmüştür.

\section{İstatistiksel Analiz}

Veriler SPSS 22 programında değerlendirilmiştir. Öğrencilerin sosyo-demografik özelliklerinin değerlendirilmesinde sayı ve yüzdelik dağılım kullanılmış, ölçek puanları ortalama ve standart sapma olarak belirtilmiştir. Sosyo-demografik özellikler ile ölçek puanlarının değerlendirilmesinde bağımsız örneklem $t$ testi, Anova ve Tukey testi kullanılmış, p<0.05 anlamlı olarak alınmıştır.

\section{Araştırmanın Etik Yönü}

Araştırmaya başlamadan önce Sivas Cumhuriyet Üniversitesi Girişimsel Olmayan Klinik Araştırmalar Etik Kurulu'ndan etik kurul onayı (karar no: 2019-01/33) ve araştırmanın yapılacağı kurumdan yazılı izin alınmıştır. Araştırmanın amacı ve konusu hakkında açıklama yapıldıktan sonra katılımcıların bilgilendirilmiş onamları alınmıştır. Katılımcılara veri toplama formu üzerinde herhangi bir kimlik bilgisi olmayacağı, formların sadece araştırma kapsamında kullanılacağı, istedikleri zaman araştırmadan vaz geçebileceği açıklanmıştır.

\section{Bulgular}

\section{Sosyo-demografik Özellikler}

Araştırmaya alınan katılımcıların yaş ortalaması 20.43 1.71 (min-max: 18-35), \%50.2'si 20-21 yaş arasındadır. Katılımcıların \%29.4'ü ( $n=78$ ) birinci sınıf, \%26.4'ü ( $n=70)$ ikinci sınıf, \%23.8'i (n=63) üçüncü sınıf ve \%20.4'ü ( $n=54)$ dördüncü sınıfta öğrenim görmektedir. Öğrencilerin \%98.5'i kadın, \%56.6'sı öğrenime başlamadan önce il merkezinde yaşamakta, $\% 72.8^{\prime} \mathrm{i}$, öğrenimi süresince yurtta yaşamaktadır. Araştırmaya alınan öğrencilerin \%88.7'si çekirdek ailede yaşamakta, \%59.6'sı aylık gelirinin idare ettiğini, \%74.3'ü 
mesleği isteyerek seçtiğini, \%87.2'si mesleği kendine uygun bulduğunu, \%54.7'si akademik başarısını orta olarak değerlendirdiğini ifade etmiştir. Katılımcıların \%12.5'i sigara, \%3'ü nargile kullandığını belirtmiştir. Sigara ve nargile kullanan öğrencilerin \%9.4'ü sigarayı, \%11.3'ü de nargileyi ara sıra kullanmaktadır (Tablo 1).

Tablo 1. Öğrencilerin sosyo-demografik özellikleri

\begin{tabular}{|c|c|c|}
\hline Özellikler & & Sayı (\%) \\
\hline Yaş ortalaması & $20.43 \pm 1.71$ (yaş aralığı: $18-35$ ) & \\
\hline \multirow[t]{3}{*}{ Yaş grubu } & $18-19$ & $75(28.3)$ \\
\hline & $20-21$ & $133(50.2)$ \\
\hline & 22 ve üzeri & $57(21.5)$ \\
\hline \multirow[t]{4}{*}{ Sınıf } & Birinci & $78(29.4)$ \\
\hline & İkinci & $70(26.4)$ \\
\hline & Üçüncü & $63(23.8)$ \\
\hline & Dördüncü & $54(20.4)$ \\
\hline \multirow[t]{2}{*}{ Cinsiyet } & Kadın & $261(98.5)$ \\
\hline & Erkek & $4(1.5)$ \\
\hline \multirow[t]{3}{*}{ Öğrenime başlamadan önce yaşadığı yer } & il & $150(56.6)$ \\
\hline & İlçe & $86(32.5)$ \\
\hline & Köy-kasaba & $29(10.9)$ \\
\hline \multirow[t]{3}{*}{ Öğrenimi sırasında yaşadığı yer } & Yurt & $193(72.8)$ \\
\hline & Evde arkadaşlarla & $26(9.8)$ \\
\hline & Aile ile & $46(17.4)$ \\
\hline \multirow[t]{2}{*}{ Aile tipi } & Çekirdek & $235(88.7)$ \\
\hline & Geniş & $30(11.3)$ \\
\hline \multirow[t]{3}{*}{ Aylık gelir durumu } & Yeterli & $59(22.3)$ \\
\hline & İdare ediyor & $158(59.6)$ \\
\hline & Yetersiz & $48(18.1)$ \\
\hline \multirow[t]{2}{*}{ Mesleği isteyerek seçme durumu } & Evet & $197(74.3)$ \\
\hline & Hayır & $68(25.7)$ \\
\hline \multirow[t]{2}{*}{ Mesleği kendine uygun bulma durumu } & Evet & $231(87.2)$ \\
\hline & Hayır & $34(12.8)$ \\
\hline \multirow[t]{2}{*}{ Akademik başarısını değerlendirme } & İyi & $120(45.3)$ \\
\hline & Orta & $145(54.7)$ \\
\hline \multirow[t]{3}{*}{ Sigara kullanma } & Evet & $33(12.5)$ \\
\hline & Hayır, hiç içmiyor & $207(78.1)$ \\
\hline & Ara sıra & $25(9.4)$ \\
\hline \multirow[t]{3}{*}{ Nargile kullanma } & Evet & $8(3.0)$ \\
\hline & Hayır, hiç içmiyor & $227(85.7)$ \\
\hline & Ara sıra & $30(11.3)$ \\
\hline
\end{tabular}

Riskli Davranışlar Ölçeği-Üniversite Formu ile İlgili Bulgular

Tablo 2'de katılımcıların RDÖÜF'dan aldıkları puan ortalamaları verilmiştir. Araştırmada antisosyal davranış puan ortalaması $15.54 \pm 4.10$, alkol kullanımı $9.84 \pm 3.05$, sigara kullanımı $13.06 \pm 7.17$, intihar eğilimi puan ortalaması $22.09 \pm 7.63$ 'dür. Beslenme alışkanlığı $20.88 \pm 6.30$, okul terki $7.11 \pm 3.05$ ve madde kullanımı puan ortalaması ise $9.38 \pm 1.58$ olarak saptanmıştır.

Tablo 2. Öğrencilerin Riskli Davranışlar Ölçeği-Üniversite Formu'ndan aldığı puan ortalamaları

\begin{tabular}{lll}
\hline RDÖÜF & Min-Max* & M \pm SD \\
\hline Antisosyal davranış & $10.00-30.00$ & $15.54 \pm 4.10$ \\
Alkol kullanımı & $9.00-33.00$ & $9.84 \pm 3.05$ \\
Sigara kullanımı & $8.00-38.00$ & $13.06 \pm 7.17$ \\
İntihar eğilimi & $12.00-56.00$ & $22.09 \pm 7.63$ \\
Beslenme alışkanlığı & $8.00-40.00$ & $20.88 \pm 6.30$ \\
Okul terki & $4.00-20.00$ & $7.11 \pm 3.05$ \\
Madde kullanımı & $9.00-26.00$ & $9.38 \pm 1.58$ \\
\hline
\end{tabular}

*Öğrencilerin ölçekten aldığı min-max puanlar; RDÖÜF=Riskli Davranışlar Ölçeği-Üniversite Formu 
Tablo 3'de öğrencilerin sınıf düzeylerine göre riskli davranışları görülmektedir. Üçüncü sınıf öğrencilerinin alkol kullanımı yönünden riskli davranışı birinci sınıf öğrencilerine göre ( $p=0.007)$; intihar eğilimi ikinci sınıf öğrencilerinde üçüncü sınıflara göre $(p=0.012)$; beslenme alışkanlığı üçüncü sınıflarda ikinci sınıflara göre $(p=0.009)$ istatistiksel olarak anlamlı şekilde yüksektir. Okul terki yönünden riskli davranışlar üçüncü sınıf öğrencilerinde dördüncü sınıflara göre ( $p=0.003)$; madde kullanımı üçüncü sınıflarda birinci sınıf öğrencilere göre $(p=0.040)$ istatistiksel olarak anlamlı düzeyde daha yüksektir.

Tablo 3. Öğrencilerin sınıf düzeylerine göre Riskli Davranışlar Ölçeği-Üniversite Formu alt boyut puanları

\begin{tabular}{|c|c|c|c|c|c|}
\hline \multirow[t]{2}{*}{ RDÖÜF alt boyutları } & Birinci & İkinci & Üçüncü & Dördüncü & \multirow[t]{2}{*}{$F, p$} \\
\hline & $M \pm S D$ & $M \pm S D$ & $M \pm S D$ & $M \pm S D$ & \\
\hline \multirow[t]{2}{*}{ Antisosyal davranış } & $14.71 \pm 3.39$ & $16.10 \pm 4.26$ & $16.33 \pm 5.09$ & $15.09 \pm 3.26$ & 2.523 \\
\hline & & & & & 0.058 \\
\hline \multirow[t]{2}{*}{ Alkol kullanımı } & $9.14 \pm 0.75$ & $9.57 \pm 2.15$ & $10.87 \pm 5.16$ & $10.03 \pm 2.52$ & 4.157 \\
\hline & & & & & $0.007 *$ \\
\hline \multirow[t]{2}{*}{ Sigara kullanımı } & $12.48 \pm 6.21$ & $11.70 \pm 5.65$ & $14.98 \pm 8.57$ & $13.42 \pm 8.07$ & 2.608 \\
\hline & & & & & 0.052 \\
\hline \multirow[t]{2}{*}{ İntihar eğilimi } & $22.41 \pm 6.39$ & $23.81 \pm 8.71$ & $19.53 \pm 6.30$ & $22.37 \pm 8.60$ & 3.710 \\
\hline & & & & & $0.012 *$ \\
\hline \multirow[t]{2}{*}{ Beslenme alışkanlığı } & $21.56 \pm 5.97$ & $19.25 \pm 6.54$ & $22.61 \pm 6.49$ & $19.98 \pm 5.70$ & 3.942 \\
\hline & & & & & $0.009 *$ \\
\hline \multirow[t]{2}{*}{ Okul terki } & $6.64 \pm 2.72$ & $7.41 \pm 3.00$ & $8.12 \pm 3.82$ & $6.24 \pm 2.09$ & 4.831 \\
\hline & & & & & $0.003 *$ \\
\hline \multirow[t]{2}{*}{ Madde kullanımı } & $9.19 \pm 0.66$ & $9.32 \pm 1.28$ & $9.87 \pm 2.76$ & $9.16 \pm 0.60$ & 2.813 \\
\hline & & & & & $0.040 *$ \\
\hline
\end{tabular}

*p<0.05; F=Tek yönlü varyans analizi; RDÖÜF=Riskli Davranışlar Ölçeği-Üniversite Formu

Öğrencilerin akademik başarısını algılamasına göre antisosyal davranış $(p=0.006)$, alkol $(p=0.039)$, sigara kullanımı ( $p=0.043)$, intihar eğilimi $(p=0.006)$, okul terki $(p=0.000)$ ve madde kullanımı $(p=0.023)$ yönünden riskli davranışları arasında istatistiksel olarak anlamlı bir farklılık olduğu saptanmıştır. Akademik başarısını orta düzeyde algılayan öğrencilerin beslenme alışkanlığı $(p=0.247)$ dışındaki tüm riskli davranış puanları daha yüksektir (Tablo 4).

Tablo 4. Öğrencilerin akademik başarııını algılamasına göre Riskli Davranışlar Ölçeği-Üniversite Formu alt boyut puanları

\begin{tabular}{|c|c|c|c|}
\hline \multirow[t]{2}{*}{ RDÖÜF alt boyutları } & İyi* & Orta* & \multirow[t]{2}{*}{$t, p$} \\
\hline & $\mathrm{M} \pm \mathrm{SD}$ & $\mathrm{M} \pm \mathrm{SD}$ & \\
\hline Antisosyal davranış & $14.80 \pm 3.72$ & $16.15 \pm 4.30$ & $\mathrm{t}=-2.754 ; \mathrm{p}=0.006^{* *}$ \\
\hline Alkol kullanımı & $9.44 \pm 2.18$ & $10.18 \pm 3.59$ & $t=-2.073 ; p=0.039 * *$ \\
\hline Sigara kullanımı & $12.10 \pm 6.48$ & $13.86 \pm 7.62$ & $\mathrm{t}=-2.032 ; \mathrm{p}=0.043^{* *}$ \\
\hline İntihar eğilimi & $20.70 \pm 7.12$ & $23.24 \pm 7.88$ & $t=-1.155 ; p=0.006^{* *}$ \\
\hline Beslenme alışkanlığı & $20.39 \pm 6.12$ & $21.28 \pm 6.44$ & $t=-1.160 ; p=0.247$ \\
\hline Okul terki & $6.29 \pm 2.61$ & $7.80 \pm 3.23$ & $\mathrm{t}=-4.203 ; \mathrm{p}=0.000 * * *$ \\
\hline Madde kullanımı & $9.15 \pm .80$ & $9.57 \pm 1.99$ & $\mathrm{t}=-2.285 ; \mathrm{p}=0.023^{*} *$ \\
\hline
\end{tabular}

*Öğrencilerin akademik başarısı "iyi", "orta” ve "kötü" olarak gruplandırılmış, "kötü" olarak ifade eden olmamıştır; ** $<<0.05$; t=Bağımsız örneklem t testi; RDÖÜF=Riskli Davranışlar Ölçeği-Üniversite Formu

Sigara kullanımı yönünden riskli davranışlar evde arkadaşları ile yaşayan öğrencilerde yurtta ve ailesi ile yaşayanlara $(p=0.004)$ göre; alkol kullanımı aylık gelirini yeterli olarak ifade eden öğrencilerde yetersiz olarak ifade edenlere ( $p=0.035)$ göre istatistiksel olarak anlamlı düzeyde daha yüksek saptanmıştır $(p<0.05)$. Intihar eğilimi $(p=0.008)$ ve okul terki $(p=0.006)$ mesleğini isteyerek seçmediğini belirten öğrencilerde; intihar eğilimi ise mesleği kendine uygun bulmayanlarda $(p=0.003)$ istatistiksel olarak anlamlı düzeyde daha yüksektir (Tablo 5). 
Tablo 5. Öğrencilerin bazı sosyo-demografik özelliklerine göre Riskli Davranışlar Ölçeği-Üniversite Formu alt boyut puanları

\begin{tabular}{|c|c|c|c|c|}
\hline \multirow[t]{2}{*}{ Özellikler } & \multicolumn{4}{|c|}{ RDÖÜF } \\
\hline & $\begin{array}{l}\text { Sigara kullanımı } \\
M \pm S D\end{array}$ & $\begin{array}{l}\text { Alkol kullanımı } \\
\mathrm{M} \pm \mathrm{SD}\end{array}$ & $\begin{array}{l}\text { İntihar eğilimi } \\
\text { M } \pm \text { SD }\end{array}$ & $\begin{array}{l}\text { Okul terki } \\
M \pm S D\end{array}$ \\
\hline \multicolumn{5}{|c|}{ Öğrenimi sırasında yaşadığı yer } \\
\hline Yurt & $12.55 \pm 6.54$ & $9.96 \pm 3.41$ & $21.91 \pm 7.16$ & $7.23 \pm 3.07$ \\
\hline Evde arkadaşlarla & $17.46 \pm 10.98$ & $10.11 \pm 2.56$ & $22.26 \pm 9.59$ & $7.76 \pm 3.77$ \\
\hline Aile ile & $12.71 \pm 6.31$ & $9.21 \pm 0.892$ & $22.73 \pm 8.47$ & $6.26 \pm 2.33$ \\
\hline \multirow{2}{*}{ Test } & $F=5.614$ & $\mathrm{~F}=1.219$ & $F=0.224$ & $F=2.569$ \\
\hline & $p=0.004^{*}$ & $p=0.297$ & $p=0.799$ & $p=0.079$ \\
\hline \multicolumn{5}{|l|}{ Aylık gelir durumu } \\
\hline Yeterli & $14.38 \pm 8.38$ & $10.71 \pm 4.11$ & $20.06 \pm 5.72$ & $7.00 \pm 3.20$ \\
\hline İdare ediyor & $12.61 \pm 6.82$ & $9.69 \pm 2.89$ & $22.77 \pm 7.78$ & $7.02 \pm 2.91$ \\
\hline Yetersiz & $12.91 \pm 6.62$ & $9.29 \pm 1.48$ & $22.31 \pm 8.83$ & $7.56 \pm 3.34$ \\
\hline \multirow[t]{2}{*}{ Test } & $\mathrm{F}=1.332$ & $F=3.408$ & $F=2.766$ & $F=0.623$ \\
\hline & $p=0.266$ & $\mathrm{p}=0.035^{*}$ & $p=0.065$ & $p=0.537$ \\
\hline \multicolumn{5}{|c|}{ Mesleği isteyerek seçme durumu } \\
\hline Evet & $13.24 \pm 7.40$ & $9.93 \pm 3.35$ & $21.36 \pm 7.35$ & $6.81 \pm 2.82$ \\
\hline Hayır & $12.52 \pm 6.47$ & $9.60 \pm 1.96$ & $24.20 \pm 8.11$ & $7.98 \pm 3.53$ \\
\hline \multirow[t]{2}{*}{ Test } & $\mathrm{t}=0.712$ & $\mathrm{t}=0.770$ & $t=-2.679$ & $t=-2.752$ \\
\hline & $p=0.477$ & $p=0.442$ & $\mathrm{p}=0.008^{*}$ & $p=0.006^{*}$ \\
\hline \multicolumn{5}{|c|}{ Mesleği kendine uygun bulma durumu } \\
\hline Evet & $12.87 \pm 6.98$ & $9.79 \pm 2.99$ & $21.54 \pm 7.15$ & $7.04 \pm 2.83$ \\
\hline Hayır & $14.35 \pm 8.38$ & $10.20 \pm 3.45$ & $25.76 \pm 9.72$ & $7.61 \pm 4.27$ \\
\hline \multirow[t]{2}{*}{ Test } & $\mathrm{t}=-1.122$ & $\mathrm{t}=-0.729$ & $\mathrm{t}=-3.051$ & $\mathrm{t}=-1.024$ \\
\hline & $p=0.263$ & $p=0.467$ & $\mathrm{p}=0.003^{*}$ & $p=0.307$ \\
\hline
\end{tabular}

*p<0.05; F= Tek yönlü varyans analizi; t=Bağımsız örneklem t testi; RDÖÜF=Riskli Davranışlar Ölçeği-Üniversite Formu

\section{Tartışma}

Riskli davranışların sık görüldüğü ergenlik dönemi üniversite dönemine kadar uzayabilmektedir. Üniversite döneminde olan gençlerin akademik, arkadaş grupları ve toplumsal yaşamları ile ilgili stres düzeyleri artmakta, duyguları hızla değişebilmekte ve riskli davranış eğilimlerinde artış olabilmektedir. ${ }^{2-4,12} \mathrm{Bu}$ araştırmadan elde edilen bulguların sağılı ile ilgili eğitim alan öğrenciler ile yapılan bazı çalışmalarla benzerlik gösterdiği görülmüştür. ${ }^{15-18}$ Bunun nedeni öğrencilerin yaşadıkları sıkıntıların, karşılaştıkları zorlukların benzer olması ve başa çıkmak için riskli davranışlara yönelmesi ile açıklanmıştır.

Araştırmamızda üçüncü sınıf öğrencilerinin alkol kullanımı, beslenme alışkanlığı, okul terki ve madde kullanımı yönünden, yüksek riskli davranışlara sahip oldukları bulunmuştur. Üçüncü sınıf ebelik öğrencilerinde birden fazla riskli davranış saptanması yapılan bir çalışmada üniversite öğrencilerinin yaklaşık dörtte birinin (\%28) üç ve daha fazla riskli davranışa sahip olduğunun bulunması ile benzerlik göstermiştir. ${ }^{12}$ Araştırma verilerimiz akademik yılın ikinci döneminde toplanmıştır. Ebelik eğitimi hem kuramsal hem de klinik uygulamalarda başarılı olmayı ve mezuniyet için bazı kriterleri yerine getirmeyi gerektirmektedir. ${ }^{22} \mathrm{Bu}$ nedenle riskli davranışların artmasının nedeni öğrencilerin teorik ve klinik uygulamalarda yaşadıkları stres, iş bulmaya ilişkin belirsizlikler gibi sorunlara bağlı yaşanan aşırı kaygı ile açıklanabilir. Araştırmamızda sigara kullanımına yönelik risk üçüncü sınıf öğrencilerinde en yüksek bulunmakla beraber anlamlılık saptanmamıştır. Yapılan bir araştırmada araştırma bulgumuzdan farklı olarak üniversite öğrencilerinin sigara içme davranışı birinci sınıfta en düşük düzeyde iken üçüncü sınıfta en yüksek düzeyde saptanmıştır. ${ }^{23}$ Akgün ve Şahin'in Sağlık Yönetimi ile Fizyoterapi ve Rehabilitasyon öğrencileri ile yaptıkları çalışmada benzer şekilde üçüncü sınıf öğrencilerinin okul terki puanları yüksek bulunmuş, ileri analiz sonucunda farkın birinci ve dördüncü sınıf düzeyinde olduğu saptanmıştır. ${ }^{15}$ Aynı araştırmada alkol kullanımı, beslenme alışkanlığı ve madde kullanımı yönünden anlamlı farklıık bulunmaması araştırma bulgumuzla farklııık göstermiştir. ${ }^{15}$ Bunun nedeni örneklem gruplarının farklı olması ile açıklanabilir. Yapılan bazı araştırmalarda 
sınıf düzeyi yükseldikçe riskli davranış gösterme düzeyinin de artması bizim bulgumuz ile uyumludur. ${ }^{24-26}$ Ayrıca 14-21 yaş arasındaki gençlerle yapılan bir araştırmada da yaş ilerledikçe alkol ve madde kullanımının arttığı bildirilmiştir. ${ }^{9}$ Yıldırım ve Zengin'in Tıp Fakültesi ve Hemşirelik bölümlerinde okuyan öğrenciler ile yaptığı çalışmada da okul terki yönünden Hemşirelik bölümünde okuyan öğrenciler daha riskli bulunmuş, bunun nedeni de öğrencilerin öğrenim gördükleri bölümlerinin farklı olması ile açıklanmıştır. ${ }^{16}$

İkinci sınıf öğrencileri intihar eğilimi yönünden daha yüksek riskli davranışlara sahiptir. Öğrencilerinin intihar eğilimi riskinin yüksek olmasının nedeni; üniversite yaşamının ilk yıllarında yeni bir çevreye alışma, okuduğu bölüme ve mesleğe uyum sağlama, yetişkinliğini ispat etme, stresli bir akademik müfredata sahip olma, mesleki rolleri ile ilgili karışıklıklar yaşama, uygulama alanlarında karşılaştıkları olumsuz tutum ve davranış örneklerinin olması olarak düşünülmüştür. Literatürde riskli davranışların daha çok gençlerin fiziksel ve ruhsal durumları ile ilişkili olduğu, intihar girişimlerinde artışa neden olabilecek alkol ve madde kullanımının ruhsal sağı̆ğı olumsuz etkileyebileceği belirtilmektedir. ${ }^{2,8}$ Tıp eğitimi alan öğrenciler ile yapılan bir çalışmada öğrencilerin \%26.2'sinin bir önceki yıl içinde en az iki hafta boyunca kendilerini umutsuz hissetmesi, \%5.5'inin intihar etmeyi ciddi olarak düşünmesi, \%3.6'ının gerçekten denemiş olması, bazılarının da bunu bir kereden fazla yapması dikkat çekicidir. ${ }^{27}$ Araştırmamızdaki öğrencilerin tamamına yakınının cinsiyeti kadındır. Bizim bulgumuz ile benzer şekilde yapılan çalışmalarda intihar planı ve kendine zarar verme davranışı kadın cinsiyetinde daha yüksek bulunmuştur. ${ }^{1,11,23,28,29}$ Arslantaş ve ark.'nın ebelik ve hemşirelik öğrencileri ile yaptığı araştırmada da öğrencilerin yaklaşık beşte birinin (\%23.7) yaşamının herhangi bir döneminde intihar fikrinin olduğu, yaklaşık onda birinin ise intihar girişiminde (\%8.7) bulunduğunun saptanması bu konunun önemine dikkat çekmektedir. ${ }^{17}$

Alkol, madde ve sigara kullanımı, antisosyal davranış, intihar eğilimi ve okul terki yönünden riskli davranışlar akademik başarısını "orta düzeyde" belirten öğrencilerde daha yüksektir. Hemşirelik öğrencileri ile yapılan bir çalışmada öğrencilerin yaşam biçimleri ile akademik başarıları arasında pozitif yönde bir ilişkinin saptanması bizim bulgumuzu destekler niteliktedir. ${ }^{30}$ Yapılan çalışmalardan elde edilen bulgular riskli davranışların akademik başarıyı etkileyen önemli bir faktör olduğunu göstermektedir. ${ }^{31,32}$ Ayrıca hemşirelik ve ebelik öğrencileri ile yapılan bir çalışmada akademik başarı ile sigara ve nargile içimi arasında anlamlı bir ilişki saptanırken, alkol bağımlılı̆ı arasında anlamlı bir ilişki saptanmamıştır. ${ }^{31}$ Başka bir araştırmada da araştırma bulgumuz ile uyumlu olarak akademik olarak başarısız olan 10. ve 11. sınıf lise öğrencilerinin antisosyal davranış, alkol kullanım, sigara kullanım, okul terki, madde kullanım ve intihar eğilimi riski daha fazladır. ${ }^{29}$

Evde arkadaşları ile yaşayan öğrencilerin sigara kullanımı yönünden riskli davranışları daha yüksektir. Öğrencilerin yaşadıkları yer, riskli davranışlarını etkileyen bir faktör olabilmektedir. ${ }^{33}$ Ailelerinden ayrı yaşayan gençler birbirlerinden etkilenmekte ve riskli davranışlar içeren etkinliklere yönelebilmektedir. ${ }^{1}$ Ebeveynlerin ahlaki gözetiminden uzak olmak ve rahat kuralların olması da üniversite öğrencilerini riskli davranışlarda bulunmaya teşvik edebilmektedir. ${ }^{1,13,24}$ Yapılan çalışmalarda araştırma bulgumuz ile benzer şekilde evde arkadaşları ile birlikte kalan üniversite öğrencilerinde sigara kullanımı daha yüksek bulunmuştur. ${ }^{1,34,35}$ Çamur ve ark.'nın yaptığı araştırmada evde arkadaş/kardeşle yaşayan üniversite öğrencilerinin 2,1 kez, evde yalnız yaşayanların ise 3,0 kez daha fazla riskli davranışlarda bulunduğunun saptanması araştırma bulgumuz ile uyumludur. ${ }^{36}$ Mahdavian ve Zolala'nın araştırmasında evde annesi ile yaşayan gençlerde sigara içme davranışı düşük bulunmuştur. ${ }^{37}$ Yapılan başka bir araştırmada devlet yurdunda kalan öğrencilerin sigara kullanma riskinin ailesiyle birlikte kalan veya yalnız evde kalan öğrencilere göre daha fazla olduğu saptanmıştır. ${ }^{15}$ Öğrencilerin ailesi dışında özgürce sigara içebilmesi ve uygun ortamın olması rahatça sigara içme davranışını sürdürmesine katkı sağladığı düşünülmektedir. Ayrıca Özcebe ve ark. yalnız yaşayan öğrencilerin daha yüksek düzeyde sigara kullandıklarını saptamıştır. ${ }^{33} \mathrm{Bu}$ 
bulgunun bizim bulgumuzdan farklı olmasının nedeni araştırmamızdaki öğrencilerin hiçbirinin yalnız yaşamamasıdır.

Aylık gelirini yeterli olarak ifade eden öğrencilerin alkol kullanımı yönünden riskli davranışları daha yüksektir. Ekonomik yönden yeterli gelirin olmasının alkol kullanım davranışını arttırdığı düşünülmektedir. Akgün ve Şahin ailesinin gelirini yüksek düzeyde belirten Sağlık Yönetimi ile Fizyoterapi ve Rehabilitasyon öğrencilerinin alkol kullanımı yönünden riskli davranışlarını daha yüksek saptamakla birlikte bizim bulgumuzdan farklı olarak anlamlıık olmadığını bildirmişlerdir. ${ }^{15}$ Bunun nedeni araştırmaya dahil edilen örneklem grubunun özelliklerinin farklı olması ile açıklanabilir. Tanrıkulu ve ark. yüksek geliri olan öğrencilerin diğerlerine göre alkol gibi maddeleri daha fazla kullandıklarını, Arıkan ve ark. da gelir düzeyinin yeterli olduğunu belirten üniversite öğrencilerinin alkol kullanım yönünden riskli davranışlarının daha yüksek olduğunu bildirmişlerdir. ${ }^{24,34}$ Karayağız Muslu ve Aygün gelir düzeyi yüksek olan lise öğrencilerinin riskli sağlık davranışlarının, Öngören ve ark. da asgari ücretin üç ile dört katından daha fazla geliri olduğunu belirten lise öğrencilerinde alkol kullanım riskinin daha fazla olduğunu belirtmişlerdir. ${ }^{25,29}$ Ayrıca ulusal ve uluslararası alanlarda yapılan bazı araştırma bulguları da bizim bulgumuzla uyumlu olarak gelir durumu yüksek olan üniversite öğrencilerinin daha fazla alkol tükettiklerini göstermektedir. ${ }^{2,4,18,35}$

Mesleğini isteyerek seçmediğini belirten öğrencilerde intihar eğilimi ve okul terki riski; mesleği kendine uygun bulmayan öğrencilerde ise intihar eğilimi riski daha yüksektir. Öğrencilerin mesleği benimsemesi başarısını etkileyen, davranışlarını belirleyen, kararlarını etkileyen ve gereksinimlerini şekillendiren önemli bir güç kaynağıdır. ${ }^{38}$ Bu bağlamda öğrencilerin benimsemediği bir mesleği sürdürmek istememesi nedeni ile olumsuz duygu durumu içine girmiş olabilecekleri düşünülmektedir. Lise öğrencileri ile yapılan bir araştırmada öğrencilerin okula bağlanma ve okuldan memnuniyetleri arttıkça riskli davranış gösterme düzeylerinin de azaldığı bildirilmiştir. ${ }^{25}$ Yapılan başka bir araştırmada da okuduğu bölümden memnun olmayanlarda intihar eğilim riskinin ve okul terkinin daha yüksek olduğu saptanmıştır. ${ }^{23}$ Bu bulgularının bizim araştırma bulgumuzu destekler nitelikte olduğu görülmektedir.

Bu araştırmanın bazı sınırlılıkları bulunmaktadır. Bu araştırmadan elde edilen bulgular sadece araştırmanın yapıldığı örneklem (ebelik öğrencileri / Sivas) grubunu kapsamaktadır, diğer üniversitelerde öğrenim gören öğrenciler ile genellenemez. Araştırmanın tanımlayııı türde olması ve doğrudan riskli davranışların araştırıldığı ebelik öğrencilerini kapsayan araştırmaların yeterli düzeyde olmaması da bir diğer sınırlııktır.

\section{Sonuç}

Öğrenim görülen sınıf düzeyi, yaşanan yer, akademik başarı ve aylık gelirin algılanması, mesleğin isteyerek seçilmesi ve öğrencinin mesleği kendine uygun bulması riskli davranışları etkilemektedir. Riskli davranışların önlenmesine yönelik eğitim programları, kurs gibi etkinlikler ve danışmanlık hizmetlerinin düzenlenmesi, ikinci ve üçüncü sınıf öğrencilerin riskli davranışlarının değerlendirilerek destek sağlanması önerilmektedir. Ayrıca öğrencilerin ebelik bölümüne karar vermeden önce meslek ile ilgili bilgilendirilmeleri ve kendilerine uygun mesleği seçmeleri konusunda danışmanlıklar yapılması, teorik ve uygulamalı derslerde akademik başarılarını arttıracak desteklerin sağlanması önerilmektedir.

\section{Bilgi}

Bu araştırma 6. Uluslararası 10. Ulusal Ebelik Öğrencileri Kongresi'nde (19-21 Nisan 2019, Sivas) sözel bildiri olarak sunulmuştur. Makalenin hazırlanmasında herhangi bir kişi ya da kuruluştan destek alınmamıştır. Çıkar çatışması yoktur.

\section{Etik Onay}

Cumhuriyet Üniversitesi Girişimsel Olmayan Klinik Araştırmalar Etik Kurulu (karar no: 2019-01/33) 


\section{Kaynaklar}

1. Fırat $S$, ve ark. Üniversite öğrencilerinde risk alma davranışları ve etkileyen faktörlerin incelenmesi. Adli Tıp Bülteni 2016;21(3):172-6.

2. Ameri $Z$, et al. The relationship between religion and risky behaviors among Iranian university students. J Relig Health 2017;56:2010-22.

3. Gençtanırım D. Riskli davranışlar ölçeği üniversite formu: geçerlik ve güvenirlik çalışmaları. Eğitimde ve Psikolojide Ölçme ve Değerlendirme Dergisi 2014;5(1):24-34.

4. Poscia A, et al. Risky behaviours among university students in Italy. Ann Ist Super Sanità 2015; 51(2):111-5.

5. Kürtüncü $M$, Uzun $M$, Ayoğlu FN. Ergen eğitim programının riskli sağlık davranışları ve sağlık algısına etkisi. Yükseköğretim ve Bilim Dergisi 2015;5(2):187-95.

6. Gençtanırım D, Ergene T. Riskli davranışlar ölçeğinin geliştirilmesi: geçerlik ve güvenirlik çalışmaları. International Journal of Social Science 2014;25-I:125-38.

7. MohammadpoorasI A, Ghahramanloo AA, Allahverdipour H. Risk-taking behaviors and subgrouping of college students: a latent class analysis. American Journal of Men's Health 2013;7(6):475-81.

8. Hamdan-Mansour AM, Marmash LR. Health concerns and risk behaviors among university students in Jordan. J Med J 2007;41(2):80-9.

9. Tsitsimpikou C, et al. Health risk behaviors among high school and university adolescent students. Experimental and Therapeutic Medicine 2018;16:3433-8.

10. Keller S, et al. Multiple health risk behaviours in German first year university students. Preventive Medicine 2008;46(3):189-95.

11. Havaçeliği Atlam D, Aldemir E, Altıntoprak AE. Üniversite öğrencilerinde riskli davranışların yaygınlığı ve madde kullanımı ile ilişkisi. Düşünen Adam The Journal of Psychiatry and Neurological Sciences 2017;30:287-98.

12. Abolfotouh MA, et al. Health-related lifestyles and risk behaviours among students living in Alexandria University hostels. Eastern Mediterranean Health Journal 2007;13(2):376-91.

13. Turhan $E$, ve ark. Üniversite öğrencilerinde madde kullanımı, şiddet ve bazı psikolojik özellikler. Türkiye Halk Sağlığı Dergisi 2011;9(1):33-44.

14. Oraby EE, Abdelsalam, AE, Safaa AA. Health risky behaviors among university students: prevalence and effect of health education program. The Egyptian Journal of Community Medicine 2016; 34(4):13-33.

15. Akgün R, Şahin H. A research on determining risk behavior of university students. Journal of Current Researches on Social Sciences 2018;8(4):367-82.

16. Yıldırım RV, Zengin Y. Başkent Üniversitesi Tıp Fakültesi Dönem 2 ve Sağlık Bilimleri Fakültesi Hemşirelik Bölümü 2. sınıf öğrencilerinin Riskli Davranışlar Ölçeği ve Ahlaki Olgunluk Ölçeği skorlamalarının değerlendirilmesi. Türkiye Biyoetik Dergisi; 2018;5(4):165-74.

17. Arslantaş H, ve ark. Hemşirelik ve ebelik öğrencilerinin intihar davranışına yönelik tutumları. Yeni Symposium 2019;57(2):6-12.

18. Pıçakçıefe M, ve ark. Bir Tıp Fakültesi birinci sınıf öğrencilerinin sosyodemografik özellikleri, olumlu, olumsuz duyguları ve riskli davranışları arasındaki ilişki. Nobel Med 2017;13(3):48-56.

19. Sohrabivafa M, ve ark. Prevalence of risky behaviors and related factors among students of Dezful. Iran J Psychiatry 2017;12(3):188-193.

20. Peltzer, ve ark. Comparison of health risk behavior, awareness, and health benefit beliefs of health science and non-health science students: an international study. Nursing and Health Sciences 2016;18:180-187.

21. Deasy C, ve ark. Predictors of health of pre-registration nursing and midwifery students: findings from a cross-sectional survey. Nurse Education Today 2016;36:427-433.

22. Resmi Gazete. Doktorluk, hemşirelik, ebelik, diş hekimliği, veterinerlik, eczacılık ve mimarlık eğitim programlarının asgari eğitim koşullarının belirlenmesine dair yönetmelik. 2 Şubat 2008. Sayı: $2677530 . \quad$ Erişim yeri: http://www.resmigazete.gov.tr/eskiler/2008/02/20080202-9.htm.

23. Oksuz E, Malhan S. Socioeconomic factors and health risk behaviours among university students in Turkey: questionnaire study. Croat Med J 2005;46(1):66-73.

24. Arıkan I, ve ark. Üniversite öğrencilerinde riskli davranışların ve bazı sosyodemografik faktörlerin incelenmesi: bir devlet üniversitesi örneği. J Contemp Med 2017;7(4):348-54.

25. Karayağız Muslu G, Aygün Ö. Ergenlerin riskli sağlık davranışlarının ve etkileyen faktörlerin belirlenmesi. DEUHFED 2017;10(4):242-50.

26. Şimşek $H$, Çöplü $F$. Lise öğrencilerinin riskli davranışlar gösterme düzeyleri ile okula bağlanma düzeyleri arasındaki ilişkinin incelenmesi. Ahi Evran Üniversitesi Sosyal Bilimler Enstitüsü Dergisi (AEÜSBED) 2018;4(1):18-30.

27. Sorush Z, ve ark. High-risk behaviors in medical students: a cross-sectional study from Tehran, Iran. Mod Care J 2018;15(3):e69327.

28. Faria YO, Gandolfi L, Moura LBA. Prevalence of risk behaviors in young university students. Acta Paul Enferm 2014;27(6):591-5. 
29. Öngören B, Sarıefe H, Balcı Y. Ergenlerde riskli davranışların sosyal açıdan irdelenmesi. The Journal of Academic Social Science Studies 2017;62:333-47.

30. Bagheri Nesami $M$, ve ark. A study on the relationship between high-risk behaviors and academic achievement and identification of associated factors among students at Nasibeh school of nursing and midwifery, Sari, Iran. Tabari J Prev Med 2015;1(2):20-30.

31. Heidari M, ve ark. Relationship of lifestyle with academic achievement in nursing students. Journal of Clinical and Diagnostic Research 2017;11(3): 1-3.

32. Çavuş FÖ, Çavuş UY, Görpelioğlu S. Ankara ilindeki ergenlerde riskli davranışların sıklığı, dağılımı. Türk Aile Hek Derg 2017;21(1):2-16.

33. Özcebe H, ve ark. Risky behaviors of university students: a cross-sectional study. Turkish Journal of Public Health 2012;10(1):112.

34. Tanrıkulu AÇ, ve ark. Kars il merkezinde çeşitli üniversite öğrencileri arasında sigara kullanım sıklı̆̆ı ve risk faktörleri. Tur Toraks Der 2009;11:101-6.

35. Ulukoca N, Gökgöz Ş, Karakoç A. Kırklareli Üniversitesi öğrencileri arasında sigara, alkol ve madde kullanım sıklığı. Fırat Tıp Derg 2013;18(4):230-4.

36. Çamur D, ve ark. Bir üniversitenin bazı fakülte ve yüksekokullarında okuyan gençlerde bazı risk alma davranışları. Toplum Hekimliği Bülteni 2007;26(3):32-8.

37. Mahdavian M, Zolala F. Determinants of risky behaviors in youth: a gender-based study. Int J High Risk Behav Addict 2017; 6(1):e23604.

38. Ay F, ve ark. Ebelik öğrencilerinin meslek algıları ve kariyer planlarını etkileyen faktörler. Balikesir Saglik Bil Derg 2018;7(2):7482. 